\title{
The Natural History of Sickle Cell Disease
}

\author{
Graham R. Serjeant \\ Sickle Cell Trust (Jamaica), Kingston 6, Jamaica \\ Correspondence: grserjeant@cwjamaica.com
}

\begin{abstract}
The term sickle cell disease embraces a group of genetic conditions in which pathology results from the inheritance of the sickle cell gene either homozygously or as a double heterozygote with another interacting gene. The spectrum of resulting conditions is therefore influenced by the geography of individual hemoglobin genes, but in most populations, the commonest genotype at birth is homozygous sickle cell (SS) disease. Because this genotype generally manifests a greater mortality, the relative proportion of sickle cell genotypes is influenced by age as well as the geographical distribution of individual genes.
\end{abstract}

nheritance of the abnormal sickle cell gene from one parent and a gene for normal $\mathrm{HbA}$ from the other parent results in the sickle cell trait. Persons with the sickle cell trait have a relative resistance to falciparum malaria, are less likely to get the disease, run lower parasite counts, and are less likely to die. This survival advantage is most marked during a window in early childhood between the loss of passively acquired maternal immunity and the development of active immunity, but the length and timing of this window may vary between communities and be influenced by the pattern of malarial transmission. The survival advantage relative to normal individuals with $\mathrm{HbA}$ has contributed to high frequencies of the sickle cell trait in areas with a history of malaria. The prevalence of the sickle cell trait varies markedly between different regions but reaches levels as high as $40 \%$ in some areas of sub-Saharan Africa, eastern Saudi Arabia, and central India. Persons with the sickle cell trait have both $\mathrm{HbA}$ and $\mathrm{HbS}$, with $\mathrm{HbS}$ levels between $20 \%$ and
$45 \%$, which are largely genetically determined. The levels of HbS in the sickle cell trait are not enough under normal physiological conditions to cause the problems relating to sickling except in the renal medulla where vascular damage causes an inability to concentrate the urine and a tendency to painless hematuria. Other features possibly associated with the trait include pulmonary embolism and an increased risk of sudden death under unusual physiological conditions, but these events are rare and the sickle cell trait, under normal conditions, is considered generally harmless and must remain outside the definition of sickle cell disease.

\section{GEOGRAPHY OF SICKLE CELL DISEASE}

\section{Populations of African Origin}

The sickle cell trait is widespread throughout Africa with low frequencies $(<1 \%-2 \%)$ in the north and south of the continent and high but variable frequencies throughout much of

Editors: David Weatherall, Alan N. Schechter, and David G. Nathan

Additional Perspectives on Hemoglobin and Its Diseases available at www.perspectivesinmedicine.org

Copyright (C) 2013 Cold Spring Harbor Laboratory Press; all rights reserved; doi: 10.1101/cshperspect.a011783

Cite this article as Cold Spring Harb Perspect Med 2013;3:a011783 
equatorial Africa. Characterization of the DNA structure flanking the $\beta$-globin locus of $\mathrm{HbS}$ suggests that the mutation has arisen on at least three independent occasions in the African continent, referred to as $\beta$-globin haplotypes and named after the areas where they were first described: Benin, Senegal, and Central African Republic or Bantu (Pagnier et al. 1984; Nagel et al 1985; Chebloune et al. 1988). The $\mathrm{HbC}$ trait is believed to be a relatively recent mutation limited to West Africa where it occurs at high frequencies $(>20 \%)$ in central Ghana and Burkina Faso, in only $2 \%$ in Nigeria, and does not occur, except in peoples of West African origin, in East and Central Africa. Only limited data are available on the type and distribution of $\alpha$ - and $\beta$-thalassemia genes in the African continent.

The most comprehensive data on populations of West African origin derive from the Americas and particularly from the United States and from the Caribbean. Screening of 100,000 consecutive nonoperative deliveries in the Jamaica Cohort Study found the sickle cell trait in $10.0 \%$ and the $\mathrm{HbC}$ trait in 3.6\% (Serjeant et al. 1986) and the relative frequencies among Afro-Americans were $8 \%$ and $2 \%$. In South America, these genes are largely confined to Brazil where they may occur in up to $7 \%$ of peoples of African origin.

The $\beta$-thalassemia trait derives from many different molecular mutations but their clinical significance depends on the degree of $\beta$-chain synthesis and, hence, HbA. Most common among Jamaicans are the mild $\beta^{+}$-thalassemia mutations, which occur in about $1 \%$, and are usually owing to mutations in the promoter region $(-88 \mathrm{C}>\mathrm{T},-29 \mathrm{~A}>\mathrm{G})$. The more severe $\beta^{0}$-thalassemia mutations occur in $\sim 0.5 \%$, and are usually owing to mutations in the intervening sequence (IVSII-849 A > G). When inherited with the HbS gene, sickle cell- $\beta^{+}$-thalassemia generally results in $15 \%-25 \% \mathrm{HbA}$ and a mild clinical course, whereas sickle cell- $\beta^{0}$ thalassemia has no $\mathrm{HbA}$ and is often clinically indistinguishable from homozygous sickle cell (SS) disease.

The frequencies of the genotypes of sickle cell disease at birth in Jamaica are one in 300 for SS disease, one in 500 for sickle cell-hemoglobin
C (SC) disease, one in 3000 for sickle cell- $\beta^{+}{ }_{-}$ thalassemia, and one in 7000 for sickle cell- $\beta^{0}$ thalassemia; slightly lower figures occur in the United States. Rare forms of sickle cell disease may result from the interaction of $\mathrm{HbS}$ with $\mathrm{HbD}$ Punjab, HbO Arab, and $\mathrm{Hb}$ Lepore.

\section{Populations in India and the Arabian Gulf}

In Saudi Arabia, the sickle cell trait is widespread but reaches its highest prevalence in the eastern Province. In India, the trait occurs most commonly among the tribal peoples in central India (southeastern Gujarat, Maharastra, Madhya Pradesh, Chhattisgarh, western Odisha) with a smaller focus in the south of the country (northern Tamil Nadu and Kerala), and trait frequencies as high as $40 \%$ have been described in some groups. In these areas, the DNA structure flanking the $\beta$-globin locus differs from that in African peoples, suggesting that this is a fourth independent occurrence of the $\mathrm{HbS}$ mutation and is referred to as the Asian haplotype. This haplotype is often associated with high levels of fetal hemoglobin and frequent $\alpha$-thalassemia, both of which tend to inhibit sickling and ameliorate the clinical course. Sickle cell disease in the Arabian Gulf and India is predominantly SS disease.

\section{COMPARISON OF GENOTYPES}

SS disease and sickle cell- $\beta^{0}$-thalassemia are most severe clinically and hematologically although both genotypes may vary markedly in severity. SC disease is generally mild but more prone to proliferative sickle retinopathy (PSR). Sickle cell- $\beta^{+}$-thalassemia presents a very wide clinical spectrum depending on the molecular mutation for the $\beta$-thalassemia gene and the amount of $\mathrm{HbA}$ produced. In peoples of West African origin, the sickle cell- $\beta^{+}$-thalassemia gene is associated with a mild reduction of normal $\beta$-chain synthesis, HbA levels of $15 \%-25 \%$, and generally a mild clinical course, although this genotype is also more prone to PSR. The increased risk of PSR in the generally milder forms of sickle cell disease, $\mathrm{SC}$ and $\mathrm{S} \beta^{+}$-thalassemia, remains largely unexplained. In Indians, 
the common $\beta^{+}$-thalassemia gene occurring in association with $\mathrm{HbS}$ produces only $3 \%-5 \%$ $\mathrm{HbA}$ and a generally severe clinical course.

The frequency and severity of clinical complications varies between the genotypes but there is a pattern for symptoms to be more marked in the generally severe SS and $S \beta^{0}$-thalassemia and more mild in SC disease and the West African form of $S \beta^{+}$-thalassemia with the notable exception of PSR. Much of the subsequent presentation will focus on the features of SS disease and be presented by patient age because this is a major determinant of clinical features.

\section{CLINICAL FEATURES}

\section{The First Year}

Symptoms develop as the $\gamma$-chain synthesis, which results in $60 \%-80 \%$ fetal hemoglobin $(\mathrm{HbF})$ at birth, is replaced by $\beta$-chain synthesis and increasing levels of the abnormal HbS. This transition occurs at different rates in different individuals but in some, pathological levels of HbS may be reached within $8-10$ wk of birth and potentially life-threatening complications may occur from that age. Early complications include dactylitis and death may result from the acute chest syndrome and abnormal splenic function rendering the infant prone to overwhelming septicemia and to acute splenic sequestration.

The onset of significant mortality between 6 and 12 mo implies that detection of the disease at birth is vital to implement family education and prophylactic measures; this may be a particular challenge because the mother has an apparently normal, asymptomatic child and may not understand the urgency. Overwhelming blood infections may be largely prevented by pneumococcal prophylaxis, which includes the conjugate pneumococcal vaccine at 2,4 , and 6 mo (Halasa et al. 2007), and regular penicillin (Gaston et al. 1986) although there are concerns that the conjugate vaccine may select nonvaccine serotypes (McCavit et al. 2011). Acute splenic sequestration may commence as early as 3 mo of age but is most common in the second
6 mo of life; two-thirds of attacks occur before $2 \mathrm{yr}$ of age, and events become rare after $6 \mathrm{yr}$ of age. Splenectomy has been advocated after two attacks, and instructing mothers in the detection of splenic enlargement and when to seek urgent attention has significantly reduced mortality from this complication (Emond et al. 1985). The mother also receives an important psychological message that although her child has a currently incurable disease, much can be done by close observation and simple interventions to improve its outcome.

Dactylitis, a complication caused by avascular necrosis of the bone marrow in the small bones of the hands and feet starts as early as $10-12 \mathrm{wk}$ of age and affected $50 \%$ of children by the age of $2 \mathrm{yr}$ in the Jamaican Cohort Study (Stevens et al. 1981). Attacks usually resolve over 5-7 d with simple analgesia, but commonly recur, and become rare after the age of $5 \mathrm{yr}$ when the active bone marrow withdraws from the small bones. Although most attacks resolve completely, clinically and radiologically, infection superimposed on the avascular tissue may sometimes cause premature fusion and a permanent shortening of the affected small bones. Dactylitis must be carefully explained to the mother and medical attendants because the occasional misdiagnosis of child abuse may cause great distress to the family. A history of dactylitis may predict a more severe clinical course (Miller et al. 2000).

\section{Early Years}

Acute chest syndrome is a term that has become widely used in sickle cell disease because of the complex pathology which may include components from infection, infarction, fat embolism, and pulmonary sequestration. Characterized by new pulmonary infiltrates and a very variable clinical picture including chest pain, cough, and dyspnea, this syndrome should be monitored closely clinically and by pulse oximetry. Exchange transfusion can be lifesaving when rapid deterioration signals acute pulmonary sequestration. This syndrome may also follow hypoventilation associated with the pleuritic pain of avascular necrosis of the ribs or sternum and 
may be prevented by incentive spirometry in such cases (Bellet et al. 1995). The acute chest syndrome is one of the commonest causes of death after the age of $2 \mathrm{yr}$.

Stroke is also a feature of early childhood with a median age of onset of $6 \mathrm{yr}$, some cases occurring as early as the second year of life, with an incidence of $8 \%$ by the age of $14 \mathrm{yr}$ in the Jamaican cohort (Balkaran et al. 1992). The principal pathology at this age is cerebral infarction secondary to stenosis of major cerebral vessels, even as large as the internal carotid artery. The mechanism of this pathology is poorly understood and clearly different from the small vessel occlusion characterizing other manifestations of the disease. Recurrent strokes occur within $3 \mathrm{yr}$ of the initial event in 50\%-70\% and many recurrent episodes may be prevented with chronic transfusion programs (Sarnaik et al. 1979; Pegelow et al. 1995). Risk factors include narrowing of cerebral vessels, which may be detected by transcranial Doppler, and in these, chronic transfusion has prevented the initial stroke from occurring (Adams et al. 1998).

Hypersplenism, characterized by persistent splenic enlargement, significant red cell sequestration, marked bone marrow expansion, and a new hematological equilibrium, also emerges around this age and affected 5\% of children in the Jamaican cohort. Some events resolve spontaneously; others are treated by splenectomy or chronic transfusion, but if unresolved, this complication may lead to significant morbidity and mortality. The relationship between acute splenic sequestration and hypersplenism is complex and ill understood; some episodes of acute splenic sequestration evolve into hypersplenism and episodes of acute splenic sequestration may become superimposed on hypersplenism, but the two pathologies tend to occur at different ages and have different risk factors.

The aplastic crisis also emerges as a common problem at this age and is an avoidable cause of the occasional death. Almost all clinically defined aplastic crises are owing to human parvovirus B19, which destroys the red cell precursors in the bone marrow for $8-10 \mathrm{~d}$ until neutralized by the production of parvovirusspecific IgG. In hematologically normal people, such infection reduces the reticulocyte count to zero but with a mean red cell survival of $120 \mathrm{~d}$, the hemoglobin decreases by only $0.5 \mathrm{~g} / \mathrm{dL}$. However, with red cell survival of 10-12 d typical of African SS disease, events in the bone marrow are rapidly reflected in the peripheral blood and the hemoglobin falls by $\sim 1 \mathrm{~g} / \mathrm{d}$ to life-threatening levels unless treated by transfusion. The outcome is entirely predictable and benign as long as oxygen delivery is maintained by a single unit transfusion, and immunity to parvovirus seems to be lifelong. Seroconversion, assessed by parvovirus-specific IgG, occurred in $70 \%$ by age $20 \mathrm{yr}$ in both Jamaica (Serjeant et al. 2001) and Uganda (Ndugwa et al. 2004), and most cases present clinically between 2 and $10 \mathrm{yr}$ of age.

\section{Later Childhood and Early Adolescence}

Many problems emerge in adolescence, which unfortunately coincides with the transition from pediatric to adult care when many patients are lost to regular follow-up. These problems include nocturnal enuresis, an increasing prevalence of bone pain crisis, avascular necrosis of the femoral head, leg ulceration in some communities, priapism, problems associated with delayed growth and puberty, pregnancy, and the need for effective contraception.

Nocturnal enuresis has received little attention because it is not life threatening but it may have a profound effect on behavior and social performance. Bedwetting more than or equal to twice weekly at the age of 8 yr occurred in $45 \%$ of children in the Jamaican cohort compared with 19\% among normal (AA) controls (Readett et al. 1990a). Enuretic patients tended to have higher urinary volumes and lower bladder capacity (Readett et al. 1990b). Enuresis always resolves eventually but may persist in some patients up to age $18-20 \mathrm{yr}$. The deleterious effects are more social and psychological rather than medical because of the obvious stress caused to patient and family.

The bone pain crisis, generally resulting from avascular necrosis of bone marrow, is the 
adult counterpart of dactylitis. Although commonly believed to result from vaso-occlusion and often referred to as the vaso-occlusive crisis (VOC), the bilateral, symmetrical involvement (Serjeant et al. 1994) and the common precipitation by skin cooling are difficult to explain on this basis. Bone pain crises increase in adolescence and early adult life, especially in males (Baum et al. 1987; Platt et al. 1991), and decline in both severity and frequency after the age of 25-30 yr, in most patients. Risk factors include a high hemoglobin level, low HbF level, and in the third trimester of pregnancy precipitating factors include cold exposure, infections, and stress. Although this complication is the cause of $\sim 90 \%$ of hospital admissions in the United States (Yang et al. 1995) and the United Kingdom (Brozovic et al. 1987), it is not an intrinsically severe pathology and death is unusual. The mechanism of the progressive amelioration of bone pains after $30 \mathrm{yr}$ of age is unclear but may reassure patients.

Avascular necrosis of the femoral head also results from avascular necrosis of bone marrow but because of its weight bearing in walking, secondary damage may occur to the articular surface of the femoral head. The prevalence in unselected series is uncertain although probably $\sim 10 \%$ and most commonly occurs in late adolescence. The outcome is determined by age at occurrence; infarction of the immature capital epiphysis allows remodeling and reasonable function, whereas involvement of the mature femoral head typically results in segmental damage with painful limitation of movement, which may require prosthetic surgery. Early diagnosis, for which magnetic resonance imaging (MRI) seems most sensitive, and avoidance of weight bearing may allow the bone to heal without deformity. Core decompression, presumably by relieving the intramedullary pressure, may relieve pain and improve movement (Mukisi-Mukaza et al. 2009) and possibly delay the use of total hip replacement.

Chronic leg ulceration is a major problem in adolescence but its frequency varies widely in different communities, affecting over 50\% of Jamaican patients (Cumming et al. 2008), but only $5 \%-10 \%$ of those in the United States (Koshy et al. 1989). Although rarely a cause of death, leg ulceration has a profound impact on education and subsequent employment potential, on social relationships, and may cause depression. Although characterized by a chronic healing/relapsing course, ulcers eventually heal in most patients by the age of $30 \mathrm{yr}$. The cause of the geographic variability is not currently understood.

Physical growth and sexual development are commonly delayed from a variety of mechanisms and it is necessary to reassure the families that this is characteristic of the disease and generally does not require special therapy because families may use expensive tonics to "fatten" the child with little or no effect. Body habitus may be permanently affected with the appearance of long thin limbs, narrow shoulders and hips, and a relative absence of body fat. Puberty, assessed by menarche, is delayed by an average of $2.5 \mathrm{yr}$ but there is no difference in the interval between menarche and first pregnancy. Pregnancy is associated with an increased risk of bone pain crisis, acute chest syndrome, and maternal death, especially in the last trimester and immediate postpartum period, and close antenatal monitoring with hospital delivery is advised. If contraception is requested, there is no evidence that any form of contraception is contraindicated in SS disease.

Priapism is a distressing complication affecting $\sim 40 \%$ of postpubertal males in Jamaica (Emond et al. 1980). Defined as painful erections unassociated with sexual desire, there are two clinical forms. Stuttering priapism, which is nocturnal, lasts $2-4 \mathrm{~h}$, with normal intervening sexual function and major attacks lasting $>12 \mathrm{~h}$ and usually followed by permanent vascular damage and impotence. Stuttering attacks interfere with sleep, leading to daytime somnolence but more importantly may be a prodrome for major events. Stuttering attacks are usually underreported because of embarrassment and the lack of realization that it is owing to sickle cell disease, so direct questioning may be necessary in its detection. The natural history is poorly documented but stuttering events generally resolve with time. 
G.R. Serjeant

\section{Later Adult Life}

A second peak of stroke occurs around $25 \mathrm{yr}$ of age and these are predominantly hemorrhagic including subarachnoid hemorrhage often secondary to berry aneurysms or direct intracerebral or intraventricular hemorrhage, which have a poor prognosis.

The acute chest syndrome continues to be a major clinical problem and increasing pulmonary fibrosis may be associated with pulmonary hypertension, placing further stress on cardiac function. Congestive cardiac failure becomes more common, possibly secondary to pulmonary hypertension, but also to a reduced compliance of the left ventricular wall secondary to the sustained hypertrophy and intraventricular fibrosis. Hemoglobin levels commonly decline over the age of $40 \mathrm{yr}$ compromising cardiac function further.

Deteriorating renal function is a major contributor to morbidity beyond the age of $40 \mathrm{yr}$, progressive glomerular fibrosis being associated with declining glomerular filtration rates (GFR), falling erythropoietin levels, and a gradual decline in total hemoglobin (Morris et al. 1991). Often clinically silent, patients do not present with the renal abnormalities but the gradually decreasing hemoglobin level impairs cardiac function. Renal failure in SS disease should be defined on the basis of lower serum creatinine levels than in the general population, and an upper limit of normal of $70-80 \mu \mathrm{mol} / \mathrm{L}$ was associated with significantly lowered GFR in the Jamaican cohort (Thompson et al. 2007).

\section{PERSPECTIVE}

From the foregoing summary of major clinical events, these are clearly influenced by patient age. The disease is asymptomatic in the first 1-2 mo of life but between 3-6 mo, dactylitis and splenic problems emerge. The second 6 mo of the first year hold serious dangers and the greatest mortality rate for the patient from acute splenic sequestration, overwhelming septicemias, and acute chest syndrome, most of which can be prevented or more effectively treated, but only if the underlying diagnosis of sickle cell disease is known, which is a major justification for newborn screening. From $1-5 \mathrm{yr}$ of age, symptoms continue to be common with dactylitis and acute splenic sequestration (both of which may recur), acute chest syndrome continues as an important problem, and stroke emerges. After age $5 \mathrm{yr}$, dactylitis becomes rare but is replaced by the adult counterpart of the bone pain crisis as active bone marrow disappears from the small bones of the hands and feet and becomes focused in the juxta-articular areas of the long bones, the vertebra, ribs, and sternum.

Adolescence is a serious time for many patients faced with enuresis, leg ulceration, increasing bone pain crisis, delayed growth and sexual development, priapism, and hip disease. Major clinical and social support is needed at this time.

In early adult life, many of these problems continue and may be amplified by the difficulties of management of pregnancy. After 25-30 yr of age, bone pain crises wane in frequency and severity and there may be a long period free of bone pains when the quality of life is better than previously and patients can engage in full-time employment and social activities and commonly default from clinic follow-up. After the age of $40 \mathrm{yr}$, renal impairment with the associated decrease in hemoglobin level becomes common and may lead to cardiac and other problems.

Overall, survival in SS disease in developed societies now shows a median survival of 45$55 \mathrm{yr}$ in the United States and Jamaica (Platt et al. 1994; Wierenga et al. 2001). However, the absence of survival data from earlier periods makes it difficult to assess whether this improvement is real or apparent because of less symptomatic bias in the observed populations. This bias, which was undoubtedly strong in the past, has been reduced by widespread population screening and especially neonatal detection, although even in the relatively short time frame of the Jamaican cohort, significantly improved survival was shown when comparing the first with subsequent terciles (Lee et al. 1995). Furthermore, there should be continued improvement because many of the interventions developed in the past $30 \mathrm{yr}$ address problems 
in early childhood and the beneficial effect of these is yet to filter through to greater survival.

The outcome of the disease in developing societies where services are less organized and resources more limited remains unknown and in sub-Saharan Africa, median survival may be $<5$ yr.

\section{DETERMINANTS OF SEVERITY}

It is likely that many factors, both genetic and environmental, determine expression and final outcome of the disease.

\section{Fetal Hemoglobin}

High levels of HbF, present at birth in virtually all patients, protect against vaso-occlusive and hemolytic features of the disease in the first few months. The level at which $\mathrm{HbF}$ persists varies widely between patients and between geographic areas but patients maintaining higher levels tend to have less hemolysis and more mild clinical courses. In African SS disease hemolysis was well established with lower hemoglobin and higher reticulocyte counts from 1 mo of age in the Jamaican cohort (Serjeant et al. 1981). In the Asian haplotype, higher $\mathrm{HbF}$ levels persist and are associated with a milder clinical course and probably greater survival but may render patients more prone to hypersplenism. The genetics of the persistence of $\gamma$ chain synthesis allowing $\mathrm{HbF}$ to persist is complex, but patients with higher $\mathrm{HbF}$ levels tend to have one or both parents with the sickle cell trait and a modest elevation of HbF suggesting a genetic mechanism that is not yet clearly defined.

\section{$\alpha$-Thalassemia}

Deletion of one of a pair of closely linked $\alpha$ thalassemia genes (heterozygous $\alpha^{+}$-thalassemia) in SS disease tends to lower the mean cell hemoglobin concentration (MCHC), which as a determinant of $\mathrm{HbS}$ polymerization (Seakins et al. 1973), is likely to reduce intravascular sickling. Deletion of both of the closely linked $\alpha$-thalassemia genes (homozygous $\alpha^{+}$-thalassemia) has an even greater effect in lowering the $\mathrm{MCHC}$ but any consequent reduction in sickling may be offset by an increase in total hemoglobin. $\alpha$-Thalassemia therefore may provide a fascinating model to distinguish the effects of inhibiting sickling in small vessels and the potentially deleterious effect of a higher hematocrit impairing blood flow in larger vessels. In African SS disease in Jamaica, heterozygous $\alpha^{+}$-thalassemia occurred in 35\% and homozygous $\alpha^{+}$-thalassemia patients in 4\% (Higgs et al. 1982), whereas in the Asian haplotype even higher levels have been found (Kar et al. 1986; Padmos et al. 1991).

\section{$\mathrm{MCHC}$}

Greece is the only population so far described in which SS disease is not associated with high frequencies of $\alpha$-thalassemia, yet Greek patients were found to have significantly lower MCHC and features of milder disease compared with Jamaicans (Christakis et al. 1990). The lowered $\mathrm{MCHC}$ in this population remains to be confirmed and the mechanism explored.

\section{Environmental Factors}

The importance of environmental factors in the outcome of sickle cell disease is undoubted, whether it relates to climatic factors or skin cooling precipitating bone pain crises or apparently random events such as contact with Streptococcus pneumonia or parvovirus B19. Malaria continues to be a major determinant of morbidity and mortality in affected areas such as sub-Saharan Africa and central India. Susceptibility to other potentially serious infections by Salmonella spp. may reflect carriage rates in the general population. Other important factors are nutrition, access to public health measures such as immunization, and socioeconomic status, which may determine the families' access to communication, transport, and medical care. The importance of environmental influences and their mechanisms hold great potential for increasing the understanding and further amelioration of sickle cell disease. 
G.R. Serjeant

\section{Genetic versus Environmental Factors Modifying SS Disease}

One of the classic methods for distinguishing genetic from environmental influences is the study of identical twins. Identical or monozygotic twins occur in $0.3 \%-0.4 \%$ of births, but to be useful for studies of hematology and clinical features, both twins must survive long enough to provide adequate data. These conditions are not frequently met and the largest available series contained six pairs of identical twins in Jamaica (Weatherall et al. 2005). A comparison of twin pairs showed that genetic factors influenced growth and hematological indices but that clinical events in the twin pairs were frequently discordant, suggesting the importance of nongenetic influences.

\section{GEOGRAPHIC VARIABILITY}

Reflecting both genetic and environmental factors is the variability of SS disease in different geographic areas. The $\beta$-globin haplotypes probably represent separate occurrences of the $\mathrm{HbS}$ mutation and do show minor differences in disease features depending on the DNA structures on which such mutations occurred. Comparison of features in the three principal African haplotypes, Benin, Bantu, and Senegal, have been difficult to conduct because of the dominance of the Benin haplotype in the United States and the Caribbean but the approximately equal prevalence in Brazil should allow comparison of Benin and Bantu haplotypes. Most studies currently available have been small and reached conflicting conclusions. In the Eastern Province of Saudi Arabia and central India, the Asian haplotype appears to have less hemolysis, greater persistence of splenomegaly, generally more mild clinical features, and probably greater survival, although the extent to which this is owing to the haplotype or to the commonly coinherited genes for $\alpha$-thalassemia and persistence of $\mathrm{HbF}$ remains unclear.

\section{CAUSES OF DEATH}

The causes of death are strongly influenced by the prevalence of malaria and other infections, and almost certainly by the availability and sophistication of medical and other services. No systematic data are available in sub-Saharan Africa but survival is likely to be markedly shortened and median duration may be as short as $5 \mathrm{yr}$.

African SS disease in the United States, where malaria is absent, has a much better prognosis, although even under the most sophisticated conditions, median survival is shortened by at least $20 \mathrm{yr}$ relative to the general population. Mortality patterns are undoubtedly changing because of diagnosis by newborn screening and more effective interventions, but an earlier review in Jamaica indicated that the highest mortality occurred in the second 6 mo of the first year of life due principally to acute splenic sequestration, the acute chest syndrome, and septicemias (Thomas et al. 1982). At later ages, acute chest syndrome persists as a major cause of death and the pattern of septicemias may be changing with the selection of penicillin-resistant and/or nonvaccine serotypes of Streptococcus pneumoniae and the emergence of Salmonella as an important organism (Wright et al. 1997). After the age of $30 \mathrm{yr}$, cumulative organ damage impairs function especially in the lungs with pulmonary fibrosis and pulmonary hypertension and in the kidney with a progressive glomerular fibrosis.

In SS disease with the Asian haplotype, almost no data are available on survival or on the causes of death although there are suggestions that cumulative end organ damage may be less common than in African SS disease.

Ascertaining the cause of death is vital to defining strategies to prevent the responsible pathologies and the dearth of available data, lack of blood and viral cultures, and of autopsies are major impediments in Africa, Arabia, and India. However, even in Jamaica, with autopsy rates as high as $90 \%$, detailed histology and blood cultures sometimes failed to detect a plausible cause of death. Furthermore, the effects on survival of recent long-term interventions such as hydroxyurea and chronic transfusion programs will need to be assessed and the current data on mortality and hydroxyurea (Steinberg et al. 2003; Bakanay et al. 2005) illustrate the complexity of interpreting results. 


\section{PREVENTION OF SICKLE CELL DISEASE}

It is now widely recognized that prevention of disease is more cost effective than trying to treat established pathology. Nowhere is this challenge more relevant than sub-Saharan Africa where figures based on population size, birth rates, and sickle cell trait frequency estimate that more than 250,000 babies with SS disease are born each year. The available resources cannot provide adequate clinical care to a problem of this scale and prevention of affected births must be one approach to the future control of the disease. Because the disease results from the inheritance of abnormal hemoglobin genes from both parents, affected children could be avoided if one parent had a normal hemoglobin (AA) genotype. Genotype identification with education and counseling on its significance would allow persons to make informed decisions on their choice of partner and should they wish, avoid the risks of a child with sickle cell disease. In Bahrain, a voluntary premarital screening program halved the births with SS disease and screening became mandatory in 2004 (Al-Arrayed 2005). The Kingdom of Saudi Arabia implemented a similar program of premarital screening in February 2004, and a review of the first $6 \mathrm{yr}$ of the program (2004-2009) indicates that out of 1.5 million marriage proposals, there had been a steadily increasing rate of marriage cancellations among at-risk couples (Memish and Saeed 2011). Among at-risk couples who continue to marry, other potential options include prenatal diagnosis and preimplantation diagnosis (Xu et al. 1999).

It remains unknown whether, in societies without traditions of arranged marriages, genotype identification and counseling at younger ages will influence reproductive decisions and such studies should have a high priority at this time. A project in Orchomenos, Greece in 1966 examined 2300 families with a sickle cell trait frequency of $23 \%$, but assessment of genotypes in 101 marriages occurring over the subsequent $7 \mathrm{yr}$ showed no significant deviation from random (Stammatoyannopoulos 1973). Factors militating against success in this study may have included the small num- bers and lack of awareness of the disease among this relatively uneducated farming community. The Manchester Project, set in the Parish of Manchester in central Jamaica, has advantages of scale and of a population with greater awareness of sickle cell disease. Screening for the detection of $\mathrm{HbS}, \mathrm{HbC}, \beta$-thalassemia trait, and other abnormal hemoglobins has been performed in approximately 16,000 senior school children aged 16-19 yrover the last 6 yr. Instead of looking at the genotypes of selected partners, this study will be based on the offspring of screened students and whether the distribution of genotypes differs from that predicted by the Hardy-Weinberg hypothesis. Newborn screening of more than 32,000 births in the parishes serving this area identified 770 babies so far born to mothers screened as school girls but much greater numbers will be needed to test the hypothesis.

Great advances have been made in the management of sickle cell disease but many of these are expensive and dependent on medical infrastructure, which may take a long time to develop in high-risk societies. In the meantime prevention, where possible, will be an essential component to overall management of the problem of sickle cell disease.

\section{REFERENCES}

Adams RJ, McKie VC, Hsu L, Files B, Vichinsky E, Pegelow C, Abboud M, Gallagher D, Kutlar A, Nichols FT, et al. 1998. Prevention of a first stroke by transfusions in children with sickle cell anemia and abnormal results on transcranial Doppler ultrasonography. N Engl J Med 339: $5-11$.

Al Arrayed S. 2005. Campaign to control genetic blood diseases in Bahrain. Community Genet 8: 52-55.

Bakanay SM, Dainer E, Clair B, Adekile A, Daitch L, Wells L, Holley L, Smith D, Kutlar A. 2005. Mortality in sickle cell patients on hydroxyurea therapy. Blood 105: 545547.

Balkaran B, Char G, Morris JS, Serjeant BE, Serjeant GR. 1992. Stroke in a cohort study of patients with homozygous sickle cell disease. J Pediatr 120: 360-366.

Baum KF, Dunn DT, Maude GH, Serjeant GR. 1987. The painful crisis of homozygous sickle cell disease: A study of risk factors. Arch Int Med 147: 1231-1234.

Bellet PS, Kalinyak KA, Shukla R, Gelfand MJ, Rucknagel DL. 1995. Incentive spirometry to prevent acute pulmonary complications in sickle cell diseases. $N$ Engl J Med 333: 699-703. 
G.R. Serjeant

Brozović M, Davies SC, Brownell AI. 1987. Acute admissions of patients with sickle cell disease who live in Britain. Br Med J 294: 1206-1208.

Chebloune Y, Pagnier J, Trabuchet G, Faure C, Verdier G, Labie D, Nigon V. 1988. Structural analysis of the $5^{\prime}$ flanking region of the $\beta$-globin gene in African sickle cell anemia patients: Further evidence for three origins of the sickle cell mutation in Africa. Proc Natl Acad Sci 85: 4431-4435.

Christakis J, Vavatsi N, Hassapopoulou H, Papadopoulou M, Mandraveli K, Loukopoulos D, Morris J, Serjeant BE, Serjeant GR. 1990. Comparison of homozygous sickle cell disease in Northern Greece and Jamaica. Lancet 335: 637-640.

Cumming V, King L, Fraser R, Serjeant G, Reid M. 2008. Venous incompetence, poverty and lactate dehydrogenase in Jamaica are important predictors of leg ulceration in sickle cell anaemia. Br J Haematol 142: 119-125.

Emond A, Holman R, Hayes RJ, Serjeant GR. 1980. Priapism and impotence in homozygous sickle cell disease. Arch Intern Med 140: 1434-1437.

Emond AM, Collis R, Darvill D, Higgs DR, Maude GH, Serjeant GR. 1985. Acute splenic sequestration in homozygous sickle cell disease: Natural history and management. J Pediatr 107: 201-206.

Gaston MH, Verter JI, Woods G, Pegelow C, Kelleher J, Presbury G, Zarkowsky H, Vichinsky E, Iyer R, Lobel JS, et al. 1986. Prophylaxis with oral penicillin in children with sickle cell anemia. A randomized trial. N Engl J Med 314: 1593-1599.

Halasa NB, Shankar SM, Talbot TR, Arbogast PG, Mitchel EF, Wang WC, Schaffner W, Craig AS, Griffin MR. 2007. Incidence of invasive pneumococcal disease among individuals with sickle cell disease before and after the introduction of the pneumococcal conjugate vaccine. Clin Infect Dis 44: 1428-1433.

Higgs DR, Aldridge BE, Lamb J, Clegg JB, Weatherall DJ, Hayes RJ, Grandison Y, Lowrie Y, Mason KP, Serjeant BE, Serjeant GR. 1982. The interaction of $\alpha$-thalassemia and homozygous sickle-cell disease. N Engl J Med 306: 1441 1446.

Kar BC, Satapathy RK, Kulozik AE, Kulozik M, Sirr S, Serjeant BE, Serjeant GR. 1986. Sickle cell disease in Orissa State, India. Lancet 328: 1198-1201.

Koshy M, Entsuah R, Koranda A, Kraus AP, Johnson R, Bellvue R, Flournoy-Gill Z, Levy P. 1989. Leg ulcers in patients with sickle cell disease. Blood 74: 1403-1408.

Lee A, Thomas P, Cupidore L, Serjeant B, Serjeant G. 1995. Improved survival in homozygous sickle cell disease: Lessons from a cohort study. Br Med J 311: 160-162.

McCavit TL, Quinn CT, Techasaensiri C, Rogers ZR. 2011. Increase in invasive Streptococcus pneumonia infections in children with sickle cell disease since pneumococcal conjugate vaccine licensure. J Pediatr 158: 505-507.

Memish ZA, Saeed MY. 2011. Six-year outcome of the national premarital screening and genetic counseling program for sickle cell disease and $\beta$-thalassemia in Saudi Arabia. Ann Saudi Med 31: 229-235.

Miller ST, Sleeper LA, Pegelow CH, Enos LE, Wang WC, Weiner SJ, Wethers DL, Smith J, Kinney TR. 2000. Prediction of adverse outcomes in children with sickle cell disease. N Engl J Med 342: 83-89.
Morris J, Dunn D, Beckford M, Grandison Y, Mason K, Higgs DR, De Ceulaer K, Serjeant BE, Serjeant GR. 1991. The haematology of homozygous sickle cell disease after the age of forty years. Br J Haematol 77: 382-385.

Mukisi-Mukaza M, Manicom O, Alexis C, Bashoun K, Donkerwolcke M, Burny F. 2009. Treatment of sickle cell disease's hip necrosis by core decompression: A prospective case-control study. Orthop Traumatol Surg Res 95: 498-504.

Nagel RL, Fabry ME, Pagnier J, Zohoun I, Wajcman H, Baudin V, Labie D. 1985. Hematologically and genetically distinct forms of sickle cell anemia in Africa. The Senegal type and the Benin type. N Engl J Med 312: 880-884.

Ndugwa C, Kiggundu M, Cohen B, Serjeant GR. 2004. Aplastic crises and acute anaemic episodes in homozygous sickle cell disease. E Afr Med J 81: 493-494.

Padmos MA, Roberts GT, Sackey K, Kulozik A, Bail S, Morris JS, Serjeant BE, Serjeant GR. 1991. Two different forms of homozygous sickle cell disease occur in Saudi Arabia. Br J Haematol 79: 93-98.

Pagnier J, Mears JG, Dunda-Belkhodja O, Schaefer-Rego KE, Beldjord C, Nagel RL, Labie D. 1984. Evidence for the multicentric origin of the sickle cell hemoglobin gene in Africa. Proc Natl Acad Sci 81: 1771-1773.

Pegelow CH, Adams RJ, McKie V, Abboud M, Berman B, Miller ST, Olivieri N, Vichinsky E, Wang W, Brambilla D. 1995. Risk of recurrent stroke in patients with sickle cell disease treated with erythrocyte transfusions. J Pediatr 126: $896-899$.

Platt OS, Thorington BD, Brambilla DJ, Milner PF, Rosse WF, Vichinsky E, Kinney TR. 1991. Pasin in sickle cell disease. Rates and risk factors. N Engl J Med 325: 11-16.

Platt OS, Brambilla DJ, Rosse WF, Milner PF, Castro O, Steinberg MH, Klug PP. 1994. Mortality in sickle cell disease. Life expectancy and risk factors for early death. N Engl J Med 330: 1639-1644.

Readett DRJ, Morris JS, Serjeant GR. 1990a. Nocturnal enuresis in sickle haemoglobinopathies. Arch Dis Child 65: $290-293$.

Readett DRJ, Morris J, Serjeant GR. 1990b. Determinants of nocturnal enuresis in homozygous sickle cell disease. Arch Dis Child 65: 615-618.

Sarnaik S, Soorya D, Kim J, Ravindranath Y, Lusher J. 1979. Periodic transfusions for sickle cell anemia and CNS infarction. Am J Dis Child 133: 1254-1257.

Seakins M, Gibbs WN, Milner PF, Bertles JF. 1973. Erythrocyte Hb-S concentration. An important factor in the low oxygen affinity of blood in sickle cell anemia. J Clin Invest 52: $422-432$.

Serjeant GR, Grandison Y, Lowrie Y, Mason K, Phillips J, Serjeant BE, Vaidya S. 1981. The development of haematological changes in homozygous sickle cell disease: A cohort study from birth to six years. Br J Haematol 48: 533-543.

Serjeant GR, Serjeant BE, Forbes M, Hayes RJ, Higgs DR, Lehmann H. 1986. Haemoglobin gene frequencies in the Jamaican population: A study of 100,000 newborns. Br J Haematol 64: 253-262.

Serjeant GR, De Ceulaer C, Lethbridge R, Morris JS, Singhal A, Thomas PW. 1994. The painful crisis of ho- 
mozygous sickle cell disease-Clinical features. Br J Haematol 87: 586-591.

Serjeant BE, Hambleton IR, Kerr S, Kilty CG, Serjeant GR. 2001. Haematological response to parvovirus B19 infection in sickle-cell disease. Lancet 358: 1779-1780.

Stammatoyannopoulos G. 1973. Problems of screening and counseling in the hemoglobinopathies. In Proceedings of the IVth International Conference on Birth Defects, Vienna, pp. 268-276.

Steinberg MH, Barton F, Castro O, Pegelow CH, Ballas SK, Kutlar A, Orringer E, Bellevue R, Olivieri N, Eckman J, et al. 2003. Effect of hydroxyurea on mortality and morbidity in adult sickle cell anemia: Risks and benefits up to 9 years of treatment. JAMA 289: 1645-1651.

Stevens MCG, Padwick M, Serjeant GR. 1981. Observations on the natural history of dactylitis in homozygous sickle cell disease. Clin Pediatr 20: 311-317.

Thomas AN, Pattison C, Serjeant GR. 1982. Causes of death in sickle-cell disease in Jamaica. Br Med J 285: 633-635.

Thompson J, Hambleton IR, Reid M, Serjeant GR. 2007 Albuminuria and renal function in homozygous sickle cell disease: Observations from a cohort study. Arch Intern Med 167: 701-708.

Weatherall MW, Higgs DR, Weiss H, Weatherall DJ, Serjeant GR. 2005. Genotype/phenotype relationships in sickle cell disease: A pilot twin study. Clin Lab Haematol 27: 384-390.

Wierenga KJ, Hambleton IR, Lewis NA. 2001. Survival estimates for patients with homozygous sickle-cell disease in Jamaica: A clinic-based population study. Lancet 357: $680-683$.

Wright J, Thomas P, Serjeant GR. 1997. Septicemia caused by salmonella infection; an overlooked complication of sickle cell disease. J Pediatr 130: 394-399.

Xu K, Shi ZM, Veeck LL, Hughes MR, Rosenwaks Z. 1999. First unaffected pregnancy using preimplantation genetic diagnosis for sickle cell anemia. JAMA 281: 17011706.

Yang Y-M, Shah AK, Watson M, Mankad V. 1995. Comparison of costs to the health sector of comprehensive and episodic health care for sickle cell disease patients. Public Health Rep 110: 80-86. 


\title{
$\&_{\mathrm{CSH}}^{\infty} \&$ Cold Spring Harbor

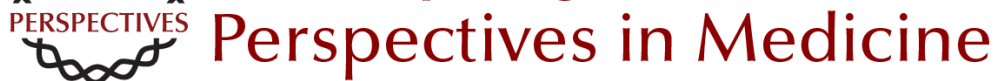

\section{The Natural History of Sickle Cell Disease}

\author{
Graham R. Serjeant
}

Cold Spring Harb Perspect Med 2013; doi: 10.1101/cshperspect.a011783 originally published online June 28, 2013

\section{Subject Collection Hemoglobin and Its Diseases}

The Natural History of Sickle Cell Disease Graham R. Serjeant

\section{Current Management of Sickle Cell Anemia} Patrick T. McGann, Alecia C. Nero and Russell E. Ware

Cell-Free Hemoglobin and Its Scavenger Proteins: New Disease Models Leading the Way to Targeted Therapies Dominik J. Schaer and Paul W. Buehler

Clinical Manifestations of $\alpha$-Thalassemia Elliott P. Vichinsky

Erythroid Heme Biosynthesis and Its Disorders Harry A. Dailey and Peter N. Meissner

Hemoglobin Variants: Biochemical Properties and Clinical Correlates Christopher S. Thom, Claire F. Dickson, David A. Gell, et al.

The Prevention of Thalassemia Antonio Cao and Yuet Wai Kan

The Switch from Fetal to Adult Hemoglobin Vijay G. Sankaran and Stuart H. Orkin
Transcriptional Mechanisms Underlying Hemoglobin Synthesis

Koichi R. Katsumura, Andrew W. DeVilbiss, Nathaniel J. Pope, et al.

Iron Deficiency Anemia: A Common and Curable Disease Jeffery L. Miller

Management of the Thalassemias Nancy F. Olivieri and Gary M. Brittenham

The Molecular Basis of $\beta$-Thalassemia Swee Lay Thein

Erythropoiesis: Development and Differentiation Elaine Dzierzak and Sjaak Philipsen

Erythropoietin

H. Franklin Bunn

Classification of the Disorders of Hemoglobin Bernard G. Forget and H. Franklin Bunn

The Molecular Basis of $\alpha$-Thalassemia Douglas R. Higgs

For additional articles in this collection, see http://perspectivesinmedicine.cshlp.org/cgi/collection/ 